\title{
Caracterización de los hormigones realizados con áridos reciclados procedentes de la industria de cerámica sanitaria
}

\section{Characterization of concrete made with recycled aggregate from ceramic sanitary ware}

\author{
C. Medina ${ }^{(*)}$, A. Juan(*), M. Frías ${ }^{(* *)}$, M. I. Sánchez de Rojas(**), J. Ma. Morán(*), M. I. Guerra(*)
}

Recepción/Received: 14-V-10

Aceptación/Accepted: 18-X-10

Publicado online/Online publishing: 11-IV-11

\section{RESUMEN}

En este estudio se plantea la posibilidad de reutilizar los residuos cerámicos de sanitarios como árido grueso sustituyendo de forma parcial $(15,20$ y $25 \%)$ al árido grueso natural. Para ello, se llevó a cabo la caracterización del árido cerámico reciclado y posteriormente se procedió a establecer los parámetros de dosificación y fabricación de los distintos hormigones. Finalmente, se realizó sobre los mismos unos ensayos de caracterización de las propiedades físicas y mecánicas, y un estudio de las fases cristalinas. Los resultados indican que a medida que se aumenta el porcentaje de sustitución se ven mejoradas las propiedades mecánicas de éstos, mientras que las propiedades físicas se mantienen prácticamente constantes. A la vista de estos resultados se puede concluir que es posible la utilización de este tipo de residuo cerámico como árido grueso en la elaboración de hormigones con fines estructurales.

Palabras clave: árido, cerámica, hormigón, caracterización, propiedades mecánicas.

\begin{abstract}
SUMMARY
This study examined the possibility of reusing the ceramic wastes of sanitary ware as coarse aggregate, in partial substitution $(15,20$ y 25\%) of natural coarse aggregates. Firstly, the characterization of recycled coarse ceramic aggregate was carried out subsequently proceeded to establish the parameters of dosage and manufacture of different concretes. Lastly, tests were conducted using these mixes to characterize physical and mechanical, and a study was carried out to identify the crystalline phases. Results showed that as the substitution proportion increased, the mechanical properties of the concrete improved, whilst physical properties remained practically constant. In view of these results, we conclude that it is possible to use this type of ceramic waste as coarse aggregate when mixing concrete destined for structural purposes.
\end{abstract}

Keywords: aggregate, ceramic, concrete, characterization, mechanical properties.

\footnotetext{
(*) Universidad de León (León, España).

(**) Instituto de Ciencias de la Construcción Eduardo Torroja (IETcc-CSIC) (Madrid, España).
} 


\section{INTRODUCCIÓN}

El desarrollo industrial y económico se ha incrementado notablemente en las últimas décadas incidiendo en la mejora de la calidad de vida y el bienestar de los ciudadanos, no obstante, conviene tener presente que todo sistema productivo origina subproductos y residuos que pueden producir alteraciones sobre el medio ambiente. Estas alteraciones pueden producirse en cualquier fase del ciclo de vida del producto: en la fase inicial de obtención de materias primas, en la fase de producción y transformación, en la distribución de los productos o, por último, cuando el poseedor tiene que desprenderse de los productos no validos.

España es el líder mundial de mercado de materiales cerámicos sanitarios. Este tipo de industria produce más de 7 millones de piezas al año (2008), según datos proporcionados por los propios fabricantes se generan en torno a $24 \mathrm{t}$ de residuos al mes que van directamente al vertedero.

En el proceso de su fabricación se genera de forma inevitable, independientemente de las mejoras que tengan lugar en los procesos de fabricación, un porcentaje de producto no apto para su comercialización, y por lo tanto de rechazo, como consecuencia de dos razones principalmente: roturas y defectos dimensionales, que no afectan a las características intrínsecas del material cerámico o bien por defectos de cocción, por exceso o por defecto y que influyen en sus características físico-químicas. El porcentaje de producto rechazado a la venta depende del tipo de planta, de los requerimientos del producto y otras consideraciones técnicas.

La gestión de estos residuos se ha convertido en una de las necesidades más urgentes de nuestro tiempo requiriendo actuaciones concretas encaminadas a la prevención de la generación de estos residuos, como, por ejemplo, el fomento de los sistemas de valorización (reutilización, reciclado y valorización energética), como forma de aprovechar los recursos que contienen los residuos, que de otro modo serían eliminados.

La presente investigación parte de la premisa de disminuir la cantidad final de residuos de la industria cerámica sanitaria que son depositados en los vertederos, preservando con ello al medio ambiente y al paisaje que nos rodea, mediante su reutilización como árido en hormigones reciclados eco-eficientes analizando su posible aplicación estructural.

\section{ESTADO DEL ARTE}

La investigación del reciclado de residuos de hormigón para la fabricación de nuevos hormigones fue iniciada

\section{INTRODUCTION}

Industrial and economic development has gathered pace considerably in recent decades, resulting in improved standards of living and wellbeing for the general population. Nevertheless, it should be borne in mind that any production system generates sub-products and waste capable of producing negative effects on the environment, and that this may happen at any point during the life cycle of the product, whether when obtaining raw materials, in the production and transformation stage, during product distribution or when defective products are discarded.

Spain is the world leader in the ceramic sanitary ware market. The industry produces over 7 million items a year (2008) and generates, according to dates the manufacturer of sanitary ware, approximately 24 tons of waste a month, which is simply dumped.

The manufacturing process inevitably generates a percentage of products deemed unsuitable for sale, regardless of any improvements made to the process. The two principle reasons for the rejection of these items are breakage or defective shape, defects which do not affect the intrinsic properties of the ceramic material, or firing defects as a result of too much or too little heat, which in this case do affect the physico-chemical properties. The percentage of rejected material depends on the type of factory, the product requirements and other technical considerations.

The need to manage these wastes has become one of the most pressing issues of our times, requiring specific actions aimed at preventing waste generation such as promotion of resource recovery systems (reuse, recycling and waste-to-energy systems) as a means of exploiting the resources contained within waste, which would otherwise be lost..

The aim of the present study was to contribute towards the preservation of the environment and landscape by reducing the final amount of ceramic sanitary ware waste deposited in refuse dumps through reuse as recycled aggregate in eco-efficient concrete, and to this end the possible structural applications were analysed.

\section{STATE OF THE ART}

The first research into recycling concrete waste to make new concrete was carried out by Glushge in Russia, in 1946 
por Glushge en Rusia en el año 1946 (1). En los años posteriores, una gran cantidad de trabajos han sido llevados a cabo en todo el mundo centrándose en la caracterización de los áridos reciclados, diseño de mezclas y análisis del comportamiento mecánico y de durabilidad de los hormigones reciclados. Fruto de este gran número de investigaciones son las distintas recomendaciones existentes a nivel internacional (2-5) sobre la utilización de los áridos procedentes de los residuos de hormigón en la fabricación de distintos tipos de hormigones.

En España, recientemente, la nueva Instrucción de Hormigón Estructural (EHE - 08) (6) regula la utilización de este tipo de material granular mediante la introducción del Anejo 15, titulado "Recomendaciones de la utilización de áridos reciclados en hormigones", basado en los trabajos realizados por los distintos miembros pertenecientes al Grupo de Trabajo 2/5 "Hormigón Reciclado", en el que se permite única y exclusivamente la utilización de la fracción gruesa (tamaño superior a $4 \mathrm{~mm}$ ), sustituyendo un $20 \%$ (en peso) del árido natural por árido reciclado de hormigón convencional. Según los estudios $(7,8)$ no es posible utilizar el árido fino reciclado, debido a su alta capacidad de absorción y una mayor probabilidad de contener impurezas.

Bajo este contexto de llevar a cabo la reutilización de residuos, se plantea la utilización de los residuos procedentes de la industria cerámica sanitaria como árido grueso reciclado en la elaboración de hormigones con fines estructurales.

La utilización de los residuos cerámicos procedentes de la industria cerámica como áridos para la fabricación de hormigones ha sido investigada a nivel internacional de una forma menos intensa que la realizada para los residuos de la construcción y demolición (RCD).

Koyuncu et al (9), Topcu (10), de Brito et al. (11, 12), Correia et al. (13) y Bakri (14) coinciden en la posibilidad de utilizar los áridos reciclados de origen cerámico en hormigones no estructurales, con buena resistencia a la abrasión y a tracción y posibilidad de uso en losas de pavimentación (debido también a una mayor durabilidad del hormigón reciclado). Senthamarai y Devadas Manoharan (15) estudian la posibilidad de introducir el residuo procedente de la industria cerámica como árido grueso en hormigones con fines estructurales obteniendo resultados satisfactorios. Binici (16) utiliza igualmente residuos cerámicos triturados y piedra pómez como sustituto parcial de árido fino para la elaboración de morteros y hormigones, concluyendo una buena resistencia a la compresión y a la abrasión. De forma similar, Puertas et
(1). Since then, much research has been conducted throughout the world, focused on characterizing recycled aggregates, designing mixes and analyzing the mechanical behaviour and durability of recycled concrete. As a result, several international recommendations exist (2-5) concerning the use of aggregates from concrete waste for making various kinds of concrete.

Recently in Spain, the use of this kind of granular material has been regulated through the new Instructions for Structural Concrete (EHE - 08) (6), and more specifically, in the introduction to Appendix 15, entitled "Recommendations for the use of recycled aggregate in concrete", based on studies carried out by various members of the Working Group 2/5 "Recycled Concrete". These recommendations specify the use of the coarse fraction (over $4 \mathrm{~mm}$ ) only, substituting $20 \%$ (in weight) of natural aggregates with recycled conventional concrete aggregate. According to studies $(7,8)$, it is not possible to use fine recycled aggregate due to its high absorption capacity and greater probability of containing impurities.

Within this context of reusing waste, we propose here the use of waste from the ceramic sanitary ware industry as coarse recycled aggregate for concrete destined for structural purposes.

On an international level, the use of ceramic waste from the ceramics industry as aggregate in the production of concretes has not been researched as thoroughly as the use of construction and demolition waste (CDW).

Koyuncu et al (9), Topcu (10), de Brito et al. (11, 12), Correia et al. (13), and Bakri (14) agree on the viability of using recycled ceramic aggregate in non-structural concretes, which show good abrasion resistance and tensile strength, and are suitable for use as paving slabs (due also to the increased durability of recycled concrete). Senthamarai y Devadas Manoharan (15) studied the possibility of using wastes from the ceramic industry as coarse aggregate in structural concretes, and obtained satisfactory results. Binici (16) also used crushed ceramic waste and pumice stone as a partial substitute for fine aggregate in the production of mortars and concretes, concluding that these presented good compressive strength and abrasion resistance. Puertas et al. (17-19) studied 6 types of ceramic wastes, using 
al. (17-19) estudian 6 tipos de residuos cerámicos como materiales alternativos para la elaboración de crudo de cemento; el estudio establece la posibilidad de su uso, con una composición química y mineralógica adecuada, así como una cierta actividad puzolánica; otro estudio destacable es el de Portella et al. (20) en el que se analiza la posibilidad de incorporación de residuos cerámicos procedentes de porcelanas eléctricas en estructuras de hormigón, se establece la posibilidad de su reutilización pero mediante el uso de cementos resistentes a los sulfatos, debido al efecto perjudicial de ciertos subproductos que generan reacción álcali-árido. Gomes et al. $(21,22)$ estudió la viabilidad de incorporar árido grueso procedente de residuos de hormigón y de residuos de bloques de cerámica en la producción de nuevos hormigones, concluyendo que desde un punto de vista de durabilidad es posible realizar hormigones con fines estructurales con áridos reciclados pero sin llevar a cabo una sustitución total de la fracción 4-32 mm de los áridos naturales. Cachim (23) utilizó residuos procedentes de la trituración de bloques cerámicos de distinto origen como sustitutos parciales (15, 20 y $30 \%)$ del árido grueso natural, observando que para un porcentaje de sustitución del $15 \%$ no existían modificaciones en la resistencia del hormigón. Silva et al. (24) analizaron la viabilidad de utilizar los residuos de cerámica roja como sustituto parcial y total del árido fino natural, obteniendo para unos porcentajes de sustitución del 20 y $50 \%$ unos resultados siempre superiores a los registrados en el mortero de referencia, mientras que cuando se realizaba la sustitución total del árido fino natural se observaba un peor comportamiento respecto al mortero patrón.

Por otro lado, Guerra et al. (25), López et al. (26) y Juan et al. $(27,28)$ estudiaron las propiedades mecánicas y físicas de los hormigones en los que se sustituyó de forma parcial el árido grueso convencional por árido grueso cerámico procedente de la trituración de porcelana sanitaria y polvo cerámico como sustituto del árido fino natural, obteniéndose buenos resultados.

Todos los estudios que han sido mencionados han sido utilizados para plantear la metodología a seguir.

\section{PROCEDIMIENTO EXPERIMENTAL}

\subsection{Metodología}

Se ha desarrollado un plan de trabajo que podemos clasificar en tres etapas. La primera de ellas consiste en la obtención e identificación de la materia prima procedente de los productos de desecho de la industria cerámica sanitaria que han sido rechazados para la venta debido a dos causas principalmente: defectos de cocción y por them as alternative materials in the production of raw cement; the study established the feasibility of this use, demonstrating suitable chemical and mineralogical composition together with a level of pozzolanic activity. Another significant study was that of Portella et al. (20), analyzing the viability of incorporating ceramic waste from electrical porcelain in concrete structures. This study concluded that such use was possible, but only when sulphate resistant cements were used due to the detrimental effect of certain sub-products which generated an alkali-aggregate reaction. Gomes et al. $(21,22)$ studied the feasibility of incorporating coarse aggregate from ceramic block waste in the production of new concretes and concluded that in terms of durability these new concretes incorporating recycled aggregate could be used for structural purposes, but that the 4-32 $\mathrm{mm}$ fraction of natural aggregates could not be substituted in its entirety. Cachim (23) crushed and used waste from different kinds of ceramic blocks as a partial substitute $(15,20$ and 30\%) for coarse natural aggregates, observing that with $15 \%$ substitution there was no change in concrete strength. Silva et al. (24) analysed the feasibility of using red ceramic waste as a partial and total substitute for natural fine aggregates, finding that at substitution percentages of 20 and $50 \%$ results which were at all times superior to those for the reference mortar. However, when natural fine aggregate was totally substituted, behaviour was poorer than that of the reference.

Finally, Guerra et al. (25), López et al. (26) and Juan et al. $(27,28)$ studied the mechanical and physical properties of concretes in which conventional coarse aggregate had been partially substituted by coarse ceramic aggregate obtained from crushing sanitary porcelain ware, and obtained good results.

All the research cited above was consulted when designing the methodological approach of the present study.

\section{EXPERIMENTAL PROCEDURE}

\subsection{Methodology}

A three stage approach was designed. The first stage consisted in obtaining and identifying raw materials from ceramic sanitary ware rejects. There were three main reasons for considering these products unsuitable for sale: firing defects, breakage or shape defects. The second stage comprised processing (crushing and/or 
la rotura o defectos dimensionales. La segunda fase consiste en el procesamiento (trituración / tamizado) de esta materia prima obteniendo así el árido grueso reciclado que se utilizará parcialmente en la elaboración del hormigón. La tercera y última etapa consistió en la caracterización de los áridos, verificando que cumplen con los requisitos establecidos en el capítulo III de la EHE-08, determinación de las propiedades físico-mecánicas e identificación de las fases minerales mediante un estudio mineralógico de los distintos tipos de hormigones realizados.

\subsection{Materiales}

Para la fabricación del hormigón se empleó un cemento Portland puro del tipo CEM I 52.5 R que cumple con los requisitos exigidos en la Instrucción de Recepción de Cementos (RC-08).

Los áridos naturales se pueden diferenciar en dos fracciones, una la fracción gruesa (grava) correspondiente a un tamaño $>4 \mathrm{~mm}$ y un fracción fina (arena) menor de $4 \mathrm{~mm}$.

El árido cerámico reciclado procede de la trituración de residuos de la industria cerámica sanitaria. La fracción de árido reciclado a utilizar es la correspondiente al tamaño 4-12,5 mm.

El agua utilizado en la fabricación y curado del hormigón es potable, cumpliendo con todas las prescripciones señaladas en la EHE-08.

\subsection{Caracterización de los áridos y hormigón}

Las muestras de los áridos a caracterizar se obtuvieron según las normas UNE-EN 932-1 y UNE-EN 932-2, teniendo siempre presente que debemos de garantizar que sean representativas del conjunto. Las propiedades analizadas, así como su correspondiente norma, se recogen en la Tabla 1.

La determinación de la porosidad total de los áridos gruesos, natural y reciclado se ha llevado a cabo mediante la técnica conocida como Porosimetría por Intrusión sieving) the raw materials thus obtained, that is, the recycled coarse aggregate which would be used to make the concrete. The third and final stage consisted in characterizing the aggregates, verifying that they fulfilled the requisites established in Chapter III of EHE-08, determining their physical-mechanical properties and identifying their mineral phases through a mineralogical study of the different kinds of concrete thus mixed.

\subsection{Materials}

In order to mix the concrete, pure Portland cement (type CEM I 52.5 R) was used, which fulfills the specifications given in the Instructions for the Authorization of Cements (Instrucción de Recepción de Cementos: RC-08).

Natural aggregates can be divided into two fractions, the coarse fraction (gravel) corresponding to a size of > $4 \mathrm{~mm}$, and the fine fraction (sand), under $4 \mathrm{~mm}$ in size.

Recycled ceramic aggregate was produced by crushing ceramic sanitary ware waste. The aggregate fraction used corresponded to a size of 4-12.5 $\mathrm{mm}$.

The water used for making and curing the concrete was drinking water, in compliance with all regulations indicated in EHE-08.

\subsection{Aggregate and concrete characterization}

Samples of the aggregates for characterization were obtained in compliance with standards UNE-EN 932-1 and UNE-EN 932-2, and care was taken to ensure that all samples were representative. The properties analyzed, together with their corresponding standard, are shown in Table 1.

Determination of total porosity for coarse aggregates, both natural and recycled, was carried out using the Mercury Intrusion Porosimetry (MIP) technique. For this,

Tabla 1 / Table 1

Métodos de caracterización de los áridos.

Methods of characterization of aggregates.

\begin{tabular}{|c|c|}
\hline Característica / Characteristic & Norma utilizada / Standard \\
\hline Granulometría y porcentaje de finos / Particle size distribution. Assessment of fines & UNE EN 933-1 \\
\hline Densidad real de la muestra seca / Dry sample density & UNE EN 1097-6 \\
\hline Absorción de agua / Water absorption & UNE EN 1097-6 \\
\hline Índice de Lajas / Flakiness index & UNE EN 933-3 \\
\hline Coeficiente "Los Ángeles" / "Los Ángeles" coefficient & UNE EN 1097-2 \\
\hline Porosidad y distribución tamaño poros / Porosity and pore size distribution & - \\
\hline
\end{tabular}


de Mercurio (MIP). Para ello se utilizó un porosímetro de mercurio marca Micromeritics modelo 9500 que alcanza una presión de 33.000 psia (228 MPa) lo que equivale a una determinación de tamaños de poro que van desde 6 hasta $0,005 \mu \mathrm{m}$.

El análisis mineralógico realizado con el objetivo de identificar las fases minerales que se encuentran presentes tanto en los áridos como en los hormigones fabricados se ha llevado a cabo mediante la técnica de Difracción de Rayos X (DRX). La medida difractométrica se efectuó con un difractómetro BRUKER Theta - Theta modelo D8 Advance sin monocromador y ánodo de Cu de 2,2 kW.

Finalmente la caracterización de las propiedades físicomecánicas de los hormigones en estado fresco y endurecido se pueden observar en la Tabla 2, junto con la normativa que se ha seguido. a mercury porosimeter (Micromeritics, model 9500) was used, which reaches a pressure of 33000 psia (228 MPa) and is capable of determining pore size within a range of 6 to $0.005 \mu \mathrm{m}$.

Mineralogical analysis was performed with the aim of identifying the mineral phases present in both the aggregates and the mixed concrete, and was carried out using the X-ray diffraction (XRD) technique. Diffractometry measurements were obtained using the BRUKER ThetaTheta diffractometer, model D8 Advance without monochromator and equipped with a $2.2 \mathrm{~kW} \mathrm{Cu}$ anode.

Characterization of the physical-mechanical properties of both fresh and hardened concrete is given in Table 2, together with the standards applied.

Tabla 2 / Table 2

Métodos de caracterización de los hormigones.

Methods of characterization of concretes.

\begin{tabular}{|c|c|}
\hline Característica / Characteristic & Norma utilizada / Standard \\
\hline Consistencia / Consistency & UNE EN 12350-2 \\
\hline Densidad en fresco / Wet density & UNE EN 12350-6 \\
\hline Resistencia a compresión / Compressive strength & UNE EN 12390-3 \\
\hline Resistencia a tracción / Splitting tensile strength & UNE EN 12390-6 \\
\hline Absorción de agua tras inmersión / Water absorption after inmersion & Normal 7/81 \\
\hline
\end{tabular}

\subsection{Diseño de las mezclas}

A partir de la bibliografía mencionada anteriormente y especialmente fijándonos en las recomendaciones que se encuentran resumidas en el anejo 15 de la EHE-08, nos proponemos fijar como porcentajes de sustitución del árido grueso convencional por el árido grueso cerámico reciclado en un 15,20 y $25 \%$.

A la hora de seleccionar un método de dosificación, entre la gran variedad de métodos existente se ha decidido utilizar el método de la Peña (29), por tratarse de uno de los métodos más utilizados en el ámbito de cálculo de dosificaciones de hormigones estructurales en España, así como porque los resultados por el mismo son semejantes, con pequeñas salvedades, a los obtenidos por el método American Concrete Institute (ACI).

Los resultados obtenidos del proceso de cálculo para los distintos tipos de hormigones se muestran en la Tabla 3.

En esta Tabla se puede observar cómo la relación a/c va aumentando a medida que se produce un aumento del contenido de árido reciclado, ya que la cantidad de agua se mantiene constante y el contenido de cemento requerido disminuye al tratarse de áridos machacados.

\subsection{Mix design}

Using the literature cited earlier, and in particular, paying special attention to the recommendations given in Appendix 15 of EHE-08, the substitution proportion of conventional coarse aggregate for recycled coarse ceramic aggregate was established as 15, 20 and 25\%.

As regards mix design, from among the wide variety of existing methods it was decided to use the de la Peña method (29) to determine the mix ratio, as this is one of the most frequently used methods for calculating structural concrete mix ratios in Spain, and because the results obtained are generally similar, with small variations, to those obtained using the American Concrete Institute (ACI) method.

The results obtained from calculations for the different types of concrete are given in Table 3.

This Table can be seen as the $w / c$ relationship will grow as there is an increase of recycled aggregate content, since the amount of water remains constant and required cement content decreases to treat aggregates crushed. 
Tabla 3 / Table 3

Dosificación de los hormigones.

Mix proportions of concretes.

\begin{tabular}{|c|c|c|c|c|c|c|}
\hline \multirow[b]{2}{*}{ Tipo hormigón / Concrete mix } & \multicolumn{5}{|c|}{ Materiales / Materials $\left(\mathbf{k g} / \mathbf{m}^{3}\right)$} & \multirow[b]{2}{*}{$a / c / w / c$} \\
\hline & $\begin{array}{l}\text { Arena I } \\
\text { Sand }\end{array}$ & $\begin{array}{l}\text { Grava I } \\
\text { Gravel }\end{array}$ & $\begin{array}{l}\text { Cerámica I } \\
\text { Ceramic }\end{array}$ & $\begin{array}{c}\text { Cemento I } \\
\text { Cement }\end{array}$ & $\begin{array}{l}\text { Agua I } \\
\text { Water }\end{array}$ & \\
\hline Hormigón referencia / Reference concrete (CR) & 716.51 & 1115.82 & 0.00 & 398.52 & 205.00 & 0.52 \\
\hline $\begin{array}{l}\text { Hormigón con } 15 \% \text { árido reciclado / Concrete containing } \\
15 \% \text { recycled aggregate (CC- } 15)\end{array}$ & 723.48 & 948.45 & 162.32 & 390.36 & 205.00 & 0.54 \\
\hline $\begin{array}{l}\text { Hormigón con } 20 \% \text { árido reciclado / Concrete containing } \\
20 \% \text { recycled aggregate (CC- } 20)\end{array}$ & 725.81 & 892.66 & 216.43 & 387.64 & 205.00 & 0.54 \\
\hline $\begin{array}{l}\text { Hormigón con } 25 \% \text { árido reciclado / Concrete containing } \\
25 \% \text { recycled aggregate (CC- } 25)\end{array}$ & 728.14 & 836.87 & 270.53 & 384.91 & 205.00 & 0.55 \\
\hline
\end{tabular}

\section{RESULTADOS Y DISCUSIÓN}

\subsection{Caracterización de los áridos}

En la Figura 1 se presenta la curva granulométrica de los áridos resultante del análisis granulométrico. Se observa cómo todos los áridos presentan curvas granulométricas continuas, lo que influirá positivamente en la docilidad de los hormigones. Además es importante señalar cómo la forma de la curva que presenta el árido cerámico reciclado es muy similar a la del árido grueso natural y que el árido grueso natural es más grueso que el árido reciclado.

La Tabla 4 recoge los resultados obtenidos en la caracterización de los áridos, así como los límites exigidos en cada caso en el capítulo III de la EHE-08 y UNE EN 12620.

De acuerdo con los resultados obtenidos, el porcentaje de finos en el árido reciclado es inferior al de la grava. La densidad de la muestra seca es similar en los áridos

\section{RESULTS AND DISCUSSION}

\subsection{Aggregate characterization}

Figure 1 shows the aggregate size grading curves obtained as a result of the sieve analysis. It can be observed that all the aggregates present continuous size grading curves, which would have a positive influence on concrete mix ease to cast. Furthermore, it should be noted that the shape curve for recycled ceramic aggregate is very similar to that for natural coarse aggregate and the gravel is most coarse that of ceramic aggregate.

Table 4 presents the results obtained for aggregate characterization, together with the limits laid down in each case in chapter 3 of EHE-08 and UNE EN 12620.

Consistent with the results obtained, the fine content in the recycled aggregate was lower than that of gravel. Dry sample density was similar for all natural

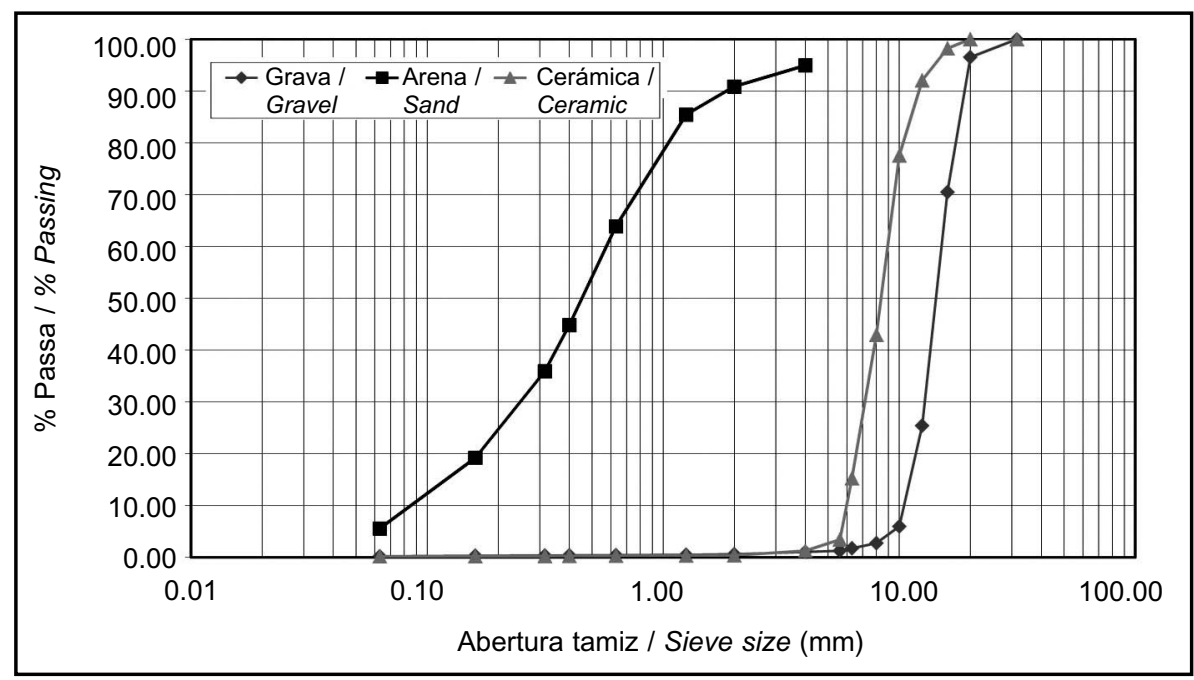

Figura 1. Curva granulométrica de los áridos. Figure 1. Aggregates size distribution curve. 
Tabla 4 / Table 4

Resultados de caracterización de los áridos. Characterization results of aggregates.

\begin{tabular}{|c|c|c|c|c|}
\hline Característica / Characteristic & Arena / Sand & Grava / Gravel & Cerámica / Ceramic & EHE-08 / UNE-EN 12620 \\
\hline Módulo granulométrico / Grading modulus & 1.28 & 6.93 & 6.17 & - \\
\hline Tamaño máximo / Maximum size (mm) & 4 & 20 & 12.5 & - \\
\hline Porcentaje de finos / Fine content (\%) & 7.52 & 0.22 & 0.16 & Arena / Sand < 10 \\
\hline $\begin{array}{c}\text { Densidad real de la muestra seca / } \\
\text { Dry sample real density (kg/dm } 3 \text { ) }\end{array}$ & 2.72 & 2.63 & 2.39 & - \\
\hline Absorción de agua / Water absorption (\%) & 2.24 & 0.23 & 0.55 & $\leq 5$ \\
\hline Índice de Lajas / Flakiness index (\%) & - & 3 & 23 & $<35$ \\
\hline Coeficiente "Los Ángeles" / "Los Ángeles" coefficient (\%) & - & 33 & 20 & $\leq 40$ \\
\hline Porosidad total / Total porosity (\%) & - & 0.23 & 0.32 & - \\
\hline
\end{tabular}

naturales pero se observa cómo en el caso del árido de origen cerámico es inferior, lo que nos permite deducir que los hormigones fabricados con los mismos serán un poco más ligeros que el hormigón de referencia. La absorción de agua del árido reciclado es superior al que presenta la grava. Este parámetro puede tener influencia en la trabajabilidad de los hormigones. Respecto al índice de lajas se puede observar una gran diferencia entre ambos áridos, resultado que puede explicarse principalmente por la forma original de los aparatos sanitarios, generalmente de poco espesor, así como al proceso de obtención del árido reciclado que ha dado lugar a áridos con aristas más marcadas y formas irregulares. En cuanto a los valores obtenidos en la determinación de la resistencia a la fragmentación, donde se observa cómo el árido reciclado presenta un valor superior de resistencia que el árido natural permitiéndonos entrever que obtendremos hormigones con mejores resistencias a la compresión.

En relación a los resultados obtenidos del estudio de la porosidad se puede apreciar, tanto en la Tabla 4 como en la Figura 2, cómo la porosidad total del árido cerámico aggregates, but this was observed to be lower in the recycled ceramic aggregate, leading us to conclude that concrete made with the latter would be slightly lighter than the reference concrete. The water absorption for the recycled aggregate was higher than that for gravel. This parameter could have an influence on the workability of the concrete mixes. As regards the flakiness index, a notable difference can be observed between these two aggregates, mainly for original shape of the sanitary ware waste, almost thin element, moreover of the process used to obtain recycled aggregate which gave rise to sharper, irregular edges. Values obtained for resistance to fragmentation indicated that the recycled aggregate presented lower values than the natural aggregate, leading us to predict that the concretes obtained with the former would have greater compressive strength.

Regarding the results obtained from the porosity study it can be seen, both in Table 4 and Figure 2, that total porosity for the recycled ceramic aggregate was slightly

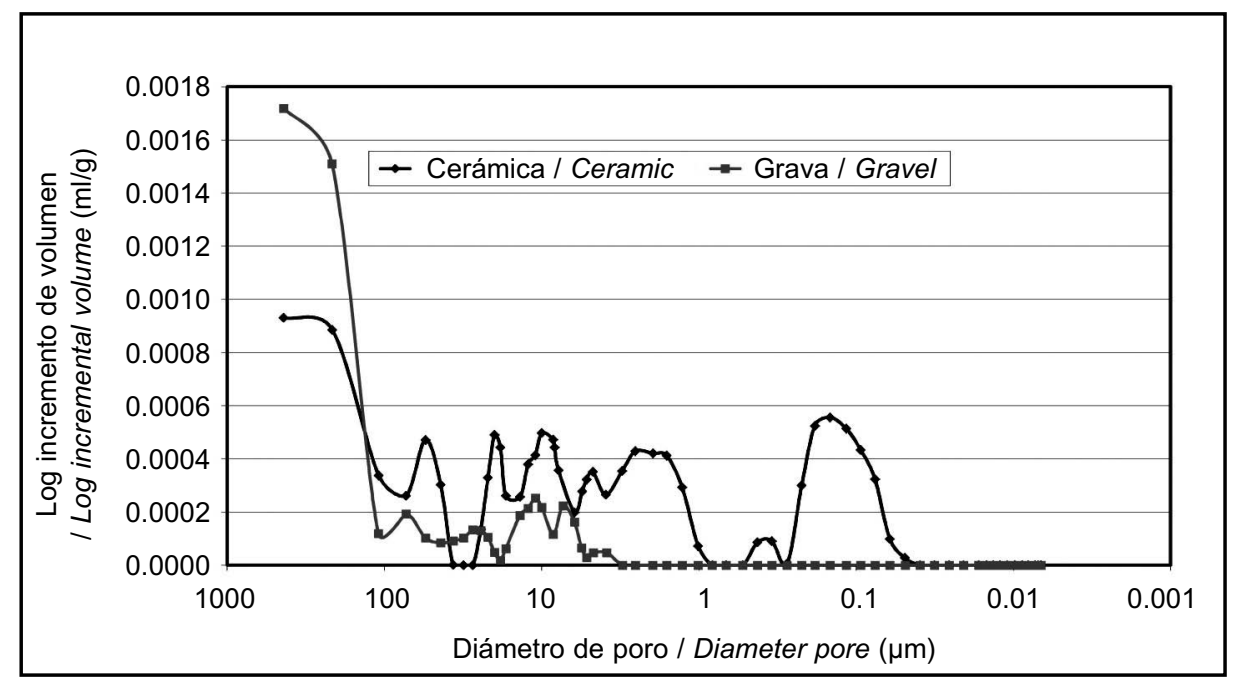

Figura 2. Distribución del tamaño de poro de los áridos gruesos. Figure 2. Pore size distribution of coarse aggregates. 
reciclado es ligeramente superior a la obtenida en el caso de la grava, lo que significa que el volumen de poros existente en la misma, es menor pero el tamaño medio de los mismos es mayor, que en el caso del árido reciclado.

Las fases minerales identificadas por DRX en caso del árido grueso natural y reciclado se recogen en las Figuras 3 y 4, respectivamente. En la Figura 3, se observa cómo la grava presenta una naturaleza silícea, presentando como mineral prioritario el cuarzo seguido en una menor proporción por otra serie de aluminosilicatos pertenecientes al grupo de la mica y de los feldespatos. En la Figura 4, se puede apreciar cómo el árido de origen cerámico presenta las fases minerales típicas de un material cerámico cocido encontrándonos principalmente cuarzo y en una menor proporción de aluminosilicatos, hematites y zircón.

\subsection{Caracterización de los hormigones}

Tras el periodo de amasado se realizó el ensayo de consistencia mediante el cono de Abrams según el cual todos los hormigones presentaron la consistencia blanda higher than that obtained for the gravel, indicating that the volume of existing pores in the latter was lower, but that their mean size was greater than in the recycled aggregate.

The mineral phases identified by XRD in natural and recycled coarse aggregates are given in Figures 3 and 4, respectively. In Figure 3, it can be observed that the gravel presented a siliceous nature, with the principal mineral being quartz, followed in a lesser proportion by a series of aluminosilicates from the mica and feldspar groups. In Figure 4, it can be seen that the recycled ceramic aggregates presented mineral phases typical of a fired ceramic material, principally quartz and to a lesser extent, aluminosilicates, hematite and zircon.

\subsection{Concrete characterization}

Following mixing, consistency tests were conducted using Abram's cone and all concrete mixes presented a soft ease to cast $(6-9 \mathrm{~cm})$, as recommended in section

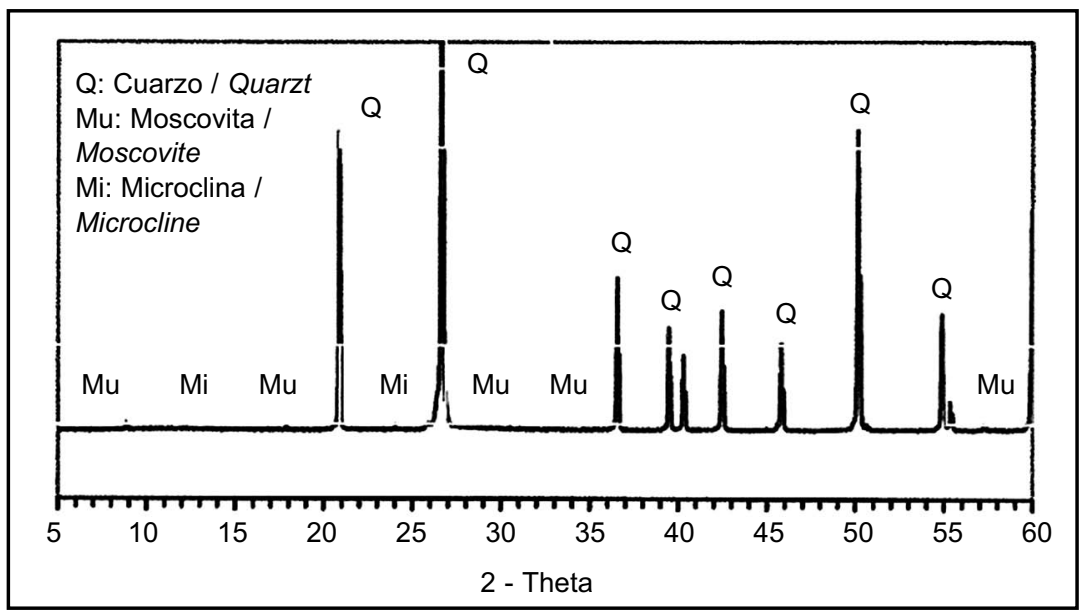

Figura 3. Difracción de rayos $X$ de la grava.

Figure 3. $X$ - ray diffration of gravel.

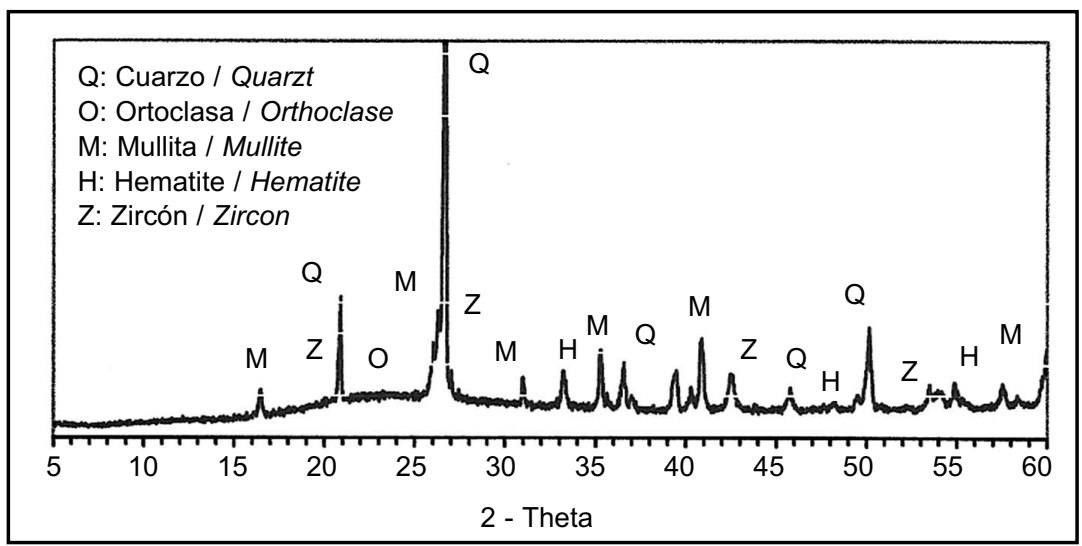

Figura 4. Difracción de rayos $X$ del árido cerámico reciclado.

Figure 4. $X$ - ray diffration of ceramic recycled aggregate. 
(6-9 cm), tal y como recomienda la EHE-08 en el apartado 31.5. En la Tabla 5 se muestran los valores de consistencia para los distintos tipos de hormigones.
31.5 of EHE-08. The values obtained in consistency tests for different types concretes are shown in Table 5.

Tabla 5 / Table 5

Consistencia del hormigón en estado fresco. Consistency of fresh concrete.

\begin{tabular}{|c|c|}
\hline Tipo hormigón / Concrete mix & Consistencia / Consistency (cm) \\
\hline Hormigón referencia / Reference concrete (CR) & 7.5 \\
\hline Hormigón con 15\% árido reciclado / Concrete containing 15\% recycled aggregate (CC-15) & 7.3 \\
\hline Hormigón con 20\% árido reciclado / Concrete containing 20\% recycled aggregate (CC-20) & 7.2 \\
\hline Hormigón con 25\% árido reciclado / Concrete containing 25\% recycled aggregate (CC-25) & 7.1 \\
\hline
\end{tabular}

Sobre todas las probetas cilíndricas $(15 \times 30 \mathrm{~cm})$ fabricadas se determinó la densidad del hormigón en estado fresco. En la Tabla 6 se observan los valores medios y las variaciones (en porcentaje), con respecto al hormigón convencional o de referencia.
All concrete sample cylinders $(15 \times 30 \mathrm{~cm})$ were tested for density while the concrete was fresh. The mean values and variations (in percentage) for conventional or reference concrete are shown in Table 6.

Tabla 6 / Table 6

Densidad media del hormigón en estado fresco.

Average density of fresh concrete.

\begin{tabular}{|c|c|c|}
\hline Tipo hormigón / Concrete mix & $\begin{array}{l}\text { Densidad media / } \\
\text { Average density }\left(\mathrm{kg} / \mathrm{dm}^{3}\right)\end{array}$ & $\begin{array}{l}\text { \% Variación respecto HR I } \\
\% \text { Variation with respect to } C R\end{array}$ \\
\hline Hormigón referencia / Reference concrete (CR) & 2.39 & 0.00 \\
\hline $\begin{array}{c}\text { Hormigón con } 15 \% \text { árido reciclado / Concrete containing } 15 \% \text { recycled } \\
\text { aggregate (CC-15) }\end{array}$ & 2.38 & -0.41 \\
\hline $\begin{array}{l}\text { Hormigón con } 20 \% \text { árido reciclado / Concrete containing 20\% recycled } \\
\text { aggregate (CC-20) }\end{array}$ & 2.37 & -0.84 \\
\hline $\begin{array}{c}\text { Hormigón con } 25 \% \text { árido reciclado / Concrete containing } 25 \% \text { recycled } \\
\text { aggregate (CC-25) }\end{array}$ & 2.36 & -1.25 \\
\hline
\end{tabular}

Tras analizar los valores obtenidos se constata que el hormigón de referencia (CR) presenta el valor más alto, con una media de $2,39 \mathrm{~kg} / \mathrm{dm}^{3}$. Los hormigones reciclados (CC-15, CC-20 y CC-25) presentan unos valores inferiores, observándose que la densidad disminuye a medida que aumenta el porcentaje de sustitución.

En la Figura 5, se representan los resultados obtenidos en el ensayo de absorción total de agua por inmersión a los distintos tipos de hormigones sobre probetas de 7,5 x $15 \mathrm{~cm}$. En ella se puede observar cómo en el caso de los hormigones con árido reciclado tardan más tiempo en llegar al estado de saturación que en el hormigón de referencia. Este hecho se puede explicar en la distribución del tamaño de poros que presenta los áridos que los constituyen.

Respecto a la resistencia a compresión, la Figura 6 representa la evolución de la resistencia a lo largo del tiempo para los distintos hormigones realizados. En ella se observa claramente que a medida que aumenta el porcentaje de sustitución del árido grueso convencional por el árido grueso reciclado aumenta la resistencia, alcanzándose en el caso del hormigón con un porcentaje de
Once the values obtained had been analyzed, it could be seen that the reference concrete $(C R)$ presented the highest value, with a mean of $2.39 \mathrm{~kg} / \mathrm{dm}^{3}$. The recycled concretes (CC-15, CC-20 and CC-25) returned lower values, and density was observed to decrease as the substitution proportion increased.

Figure 5 presents the results obtained for the water absorption assay, carried out through total immersion of sample cylinders $(7.5 \times 15 \mathrm{~cm})$ for all the different types of concrete. It can be observed that the concrete mixes incorporating recycled aggregate took longer to reach saturation than the reference concrete. This may be due to the pore size distribution of the aggregates used in the former.

As regards compressive strength, Figure 6 shows the evolution of strength over time for all concrete mixes. It is clear to see that as more conventional coarse aggregate was substituted by recycled coarse aggregate, strength increased, and where the substitution proportion reached $25 \%$ (CC-25), strength increased by $11 \%$ with respect to the reference concrete $(C R)$ at 28 


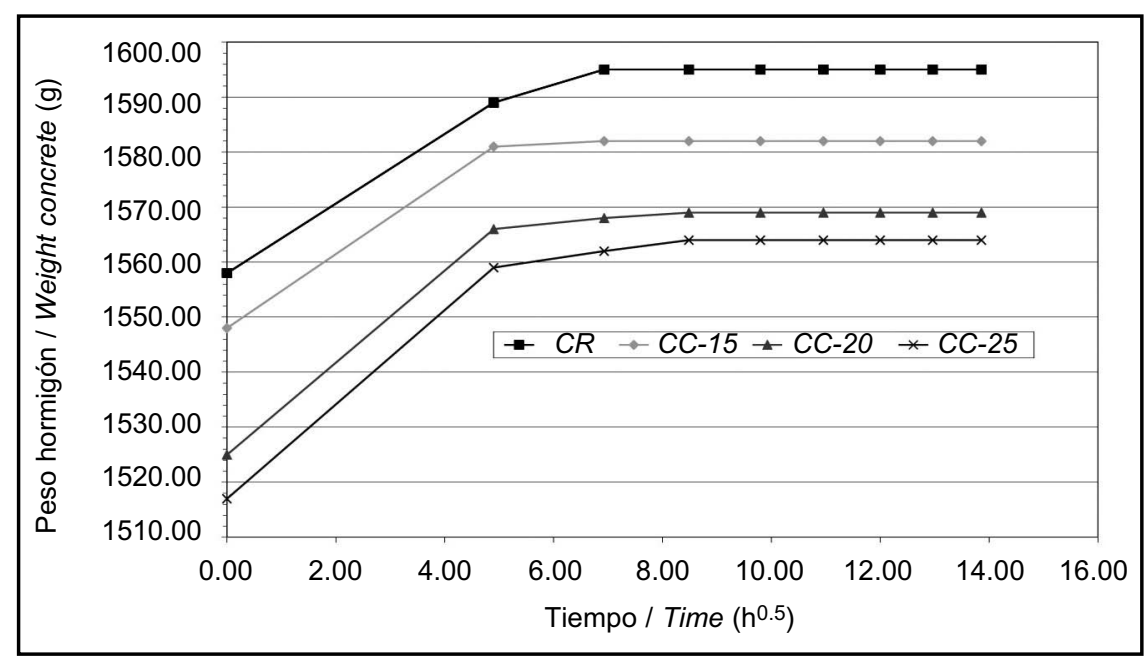

Figura 5. Absorción de agua por inmersión total.

Figure 5. Water absorption by inmersion.

sustitución del $25 \%$ (CC-25) un aumento del $11 \%$ respecto al hormigón de referencia (CR) a los 28 días, independientemente de que la relación a/c vaya aumentando, lo que nos indica el efecto beneficioso que tiene este árido reciclado en la resistencia a compresión.

En la Tabla 7 se presentan los resultados de resistencia a tracción indirecta obtenidos para cada uno de los hormigones. Del análisis de estos valores se puede sacar la conclusión de que la incorporación del árido reciclado tiene una influencia positiva y con una tendencia semejante a lo que sucede en el caso de la resistencia a compresión.

Por último, del estudio mediante DRX de las fases cristalinas presentes en el hormigón se obtuvieron los resultados que se representan en la Figura 7. En ella se observa cómo en todos los hormigones se encuentran las fases típicas resultantes del proceso de hidratación del days, regardless of whether the $w / c$ relationship increase, which tells us the beneficial effect of this recycled aggregate in this properties.

The results for splitting tensile strength obtained for each of the concrete mixes are given in Table 7. An analysis of these values leads to the conclusion that the incorporation of recycled aggregate has a positive influence, similar to that witnessed in the case of compressive strength.

Finally, the XRD study of crystalline phases present in the concrete produced the results shown in Figure 7. Here, it can be seen that all the concrete mixes presented the phases typical of the cement hydration process. Also evident is the presence of calcite, resulting

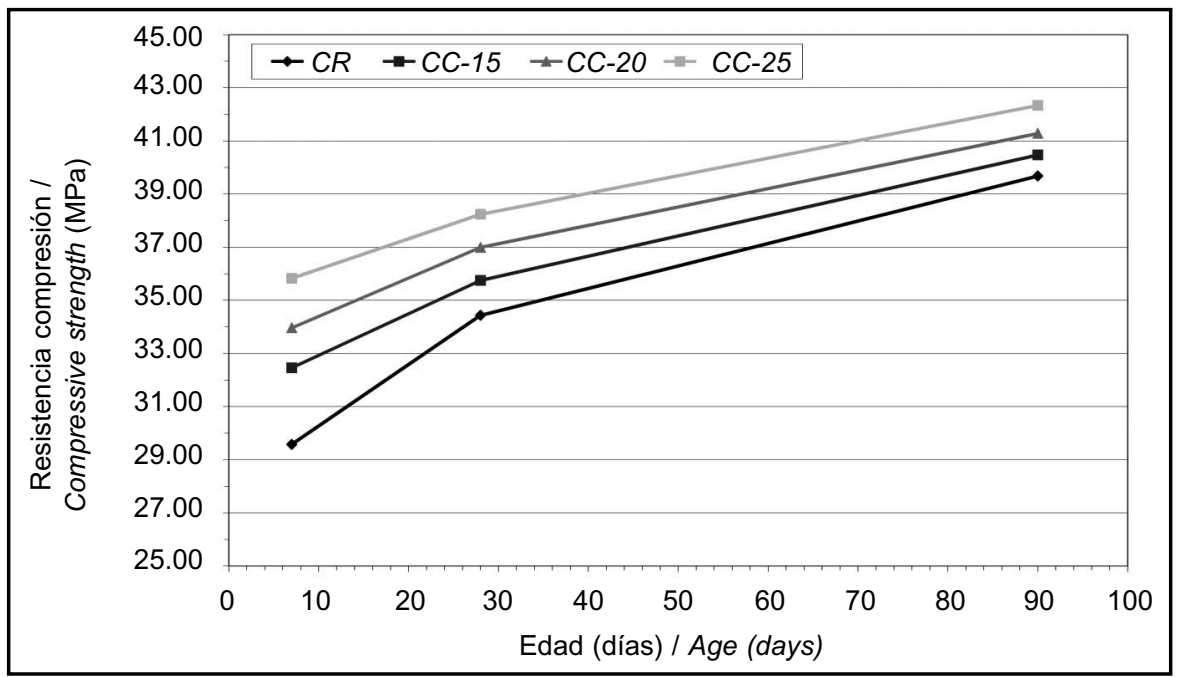

Figura 6. Evolución de la resistencia a compresión con la edad. Figure 6. Evolution of compressive strength with the age. 
cemento así como la presencia de calcita producto de la carbonatación de la muestra, por lo que en un principio el árido reciclado que se ha introducido no ha interferido en el proceso de endurecimiento del hormigón. from carbonation of the product, thus indicating that the recycled aggregate incorporated into the mix did not interfere with the concrete hardening process.

Tabla 7 / Table 7

Resistencia a tracción indirecta a 28 días. Splitting tensile strength at 28 days.

\begin{tabular}{|c|c|}
\hline Tipo hormigón / Concrete mix & $\mathbf{f}_{\mathrm{ct}}(\mathrm{MPa})$ \\
\hline Hormigón referencia / Reference concrete (CR) & 3.50 \\
\hline Hormigón con 15\% árido reciclado / Concrete containing 15\% recycled aggregate (CC-15) & 3.61 \\
\hline Hormigón con 20\% árido reciclado / Concrete containing 20\% recycled aggregate (CC-20) & 3.73 \\
\hline Hormigón con 25\% árido reciclado / Concrete containing 25\% recycled aggregate (CC-25) & 3.87 \\
\hline
\end{tabular}

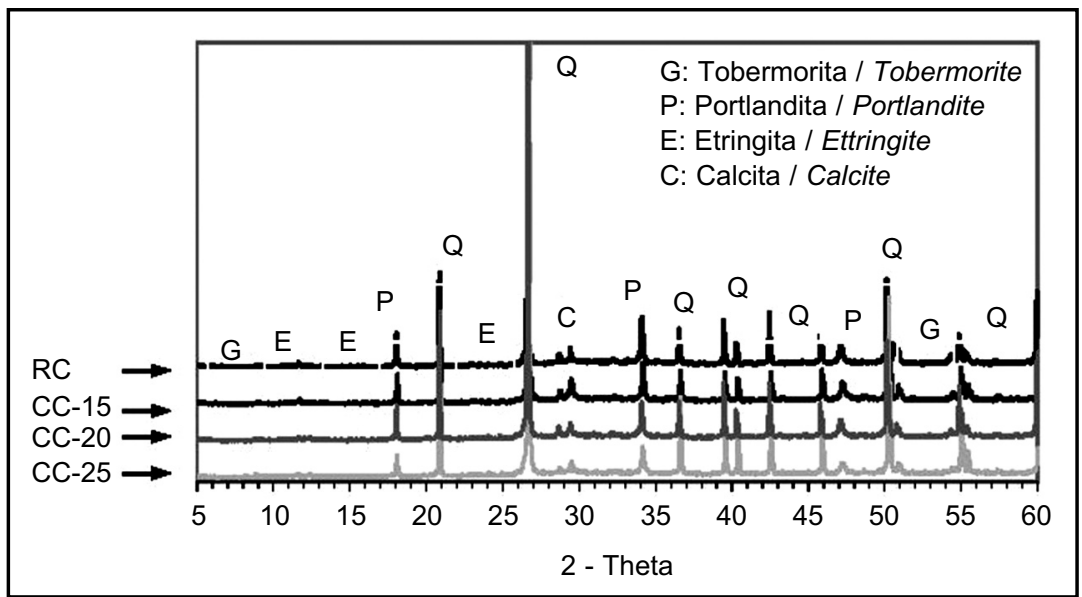

Figura 7. Difracción rayos $X$ de la pasta de los distintos hormigones. Figure 7. $X$ - ray diffraction of paste of different concretes.

\section{CONCLUSIONES}

Las principales conclusiones derivadas del presente estudio se exponen a continuación:

- Las características del árido cerámico reciclado hacen a éste adecuado, a priori, para la fabricación de hormigones estructurales cumpliendo con los requisitos establecidos en la EHE-08 y UNE-EN 12620. Destacan frente a los áridos naturales su menor densidad y su mayor resistencia a la fragmentación.

- Según los resultados obtenidos el árido cerámico reciclado no interfiere en la cinética normal de las reacciones químicas de hidratación del cemento.

- Los hormigones reciclados con un $25 \%$ de sustitución del árido grueso natural no evidencian en su fabricación un incremento de las necesidades de agua, presentando una consistencia semejante al hormigón de referencia o patrón (consistencia blanda), por lo que no existe una modificación en la trabajabilidad y docilidad de estos hormigones.

- Los hormigones reciclados presentaron valores de densidad en estado fresco inferiores a los del hormigón de

\section{CONCLUSIONS}

The main conclusions reached as a result of this present study are as follows:

- Recycled aggregate characteristics indicate that this is a priori suitable for mixing concrete destined for structural purposes and complies with the requisites established in EHE-08 and UNE-EN 12620. Of particular note is the lower density and greater resistance to fragmentation of the recycled aggregate compared with natural aggregates.

- According to results obtained the recycled ceramic aggregate does not interfere in the normal kinetic of chemical reactions which occur during cement hydration.

- Recycled concrete, where $25 \%$ of the natural coarse aggregate has been substituted by recycled ceramic aggregate, does not present increased water requirements during mixing and has a consistency similar to that of the reference concrete (soft consistency). There is, therefore, no difference in the workability and ease to cast of these concrete mixes.

- Recycled concrete mixes presented density values when fresh which were lower than that of the 
referencia y tardan un mayor tiempo en alcanzar el grado de saturación de agua.

- La resistencia a compresión y tracción indirecta han sido superiores en los hormigones reciclados que en el hormigón de referencia, observándose que a medida que el porcentaje de sustitución aumenta tiene lugar una mejoría en el comportamiento mecánico de estos hormigones reciclados eco-eficientes, con independencia de que estos hormigones reciclados presenten una relación a/c mayor que la del hormigón de referencia.

- Estos hormigones reciclados eco-eficientes obtenidos por la sustitución parcial de árido grueso natural (grava) por árido grueso cerámico procedente de los residuos de la industria cerámica podrían utilizarse para la elaboración de hormigones con fines estructurales.

\section{AGRADECIMIENTOS}

La investigación ha tenido lugar gracias a la financiación del proyecto de investigación de la Universidad de León (ULE 2009-5) "Hormigones reciclados eco-eficientes con fracción pétrea cerámica de residuos de la construcción y demolición". Además, agradecer la colaboración prestada a los miembros del Instituto de Ciencias de la Construcción Eduardo Torroja (CSIC): David Revuelta, Pedro Carballosa, Olga Rodríguez y Belén Nebreda. reference concrete, and took longer to reach water saturation.

- Compressive and splitting tensile strength was higher in recycled concrete mixes than in the reference concrete, and it was observed that as the substitution proportion increased, the mechanical behaviour of the recycled, eco-efficient concrete mixes improved, regardless of which these recycled concretes presented a ratio $w / c$ higher than the reference concrete.

- The eco-efficient recycled concrete mixes obtained through partial substitution of natural coarse aggregates (gravel) by coarse ceramic aggregate from ceramic sanitary ware waste could be employed to mix concrete destined for structural purposes.

\section{ACKNOWLEGEMENTS}

This research has been made possible thanks to funding received from the Spanish research project ULE 2009-5 "Recycled eco - efficient concretes produced with ceramic fraction from construction and demolition wastes". Besides, the authors would like to thank members of the Eduardo Torroja Institute for Construction Sciences (CSIC): David Revuelta, Pedro Carballosa, Olga Rodríguez and Belén Nebreda.

\section{BIBLIOGRAFÍA / BIBLIOGRAPHY}

(1) Glushge, P. I. "The work of the Scientific Research Institute. Gidrotskhnicheskoge Stroitelstvo, no 4, April 1946, pp. 27-28 (U.S.S.R.)". Brief English summary in Engineers Digest, vol. 7, no 10 (1946), pp. 330.

(2) RILEM. "Specifications for concrete with recycled aggregates". Materials and Structures, no 27, 1994, pp. 557-559.

(3) Psawa, F.; Noguchi, T.: "New technology for the recycling of concrete. Japanese experience". Concrete Technology for a Sustainable Development in the 21th Century, 2000, pp. 274-287.

(4) Vincke, J.; Rousseau, E.: "Recycling of construction and demolition waste in Belgium: actual situation and future evolution". Demolition and Reuse of Concrete and Masonry, Proceedings of the Third International RILEM Symposium, Edited by Lauritzen, E. K., Publisher by E\&FN Spon, 2-6 Boundary Row, London SE 18 HN, First Edition, 1994, pp. 57-69.

(5) Sagoe - Crentsil, K.; Brown, T.: "Guyde for specification of recycled concrete aggregates (RCA) for concrete production". CSIRO, Building, Construction and Engineering. Ecorecycle, Victoria. September 1998.

(6) Instrucción de hormigón estructural (EHE-08). Ministerio de Fomento, Madrid, 2008.

(7) Monografía M-11: "Utilización de árido reciclado para la fabricación de hormigón estructural", pp. 189, ASCHE, 2006.

(8) Sánchez, M; Alaejos, P.: "Influencia del árido reciclado en las propiedades del hormigón estructural". Cemento - Hormigón, junio 2006, no 889, pp. 54-61.

(9) Koyuncu, H.; Guney, Y.; Yilmaz, G.; Koyuncu, S.; Bakis, R.: "Utilization of ceramic wastes in the construction sector". Key Engineering Materials, vol. 264-268 (2004), pp. 2509-2512. DOI: 10.4028/www.scientific.net/KEM.264-268.2509.

(10) Topcu, I. B., Canbaz, M.: "Utilization of crushed tile as aggregate in concrete". Iranian Journal of Science and Technology Transaction B-Engineering, vol. 31 (2007), nº B5, pp. 561-565.

(11) de Brito, J.; Pereira, A. S.; Correia, J. R.: "Mechanical behaviour of non-structural concrete made with recycled ceramic aggregates". Cement and Concrete Composites, vol. 27 (2005), no 4, pp. 429-433. DOI: 10.1016/j.cemconcomp.2004.07.005.

(12) de Brito, J.: "Abrasion resistance of concrete made with recycled aggregates". International Journal of Sustainable Engineering, vol. 3 (2010), no 1, pp. 58-64. DOI: 10.1080/19397030903254710. 
(13) Correia, J. R.; de Brito, J.; Pereira, A. S.: "Effects on concrete durability of using recycled ceramic aggregates". Materials and Structures, vol. 39 (2006), no 2, pp. 169-177. DOI: 10.1617/s11527-005-9014-7.

(14) Bakri, M. M., Hussin, K.; Mohd, C.; Baharin, S.; Ramly, R.; Khairiatun, N.: "Concrete Ceramic Waste Slab (CCWS)". Journal of Engineering Research \& Education, vol. 3 (2006), pp. 139-145.

(15) Senthamarai, R. M.; Devadas Manhoharan, P.: "Concrete with ceramic waste aggregate". Cement \& Concrete Composites, vol. 27 (2005), no 9-10, pp. 910-913. DOI: 10.1016/j.cemconcomp.2005.04.003.

(16) Binici, H.: "Effect of crushed ceramic and basaltic pumice as fine aggregates on concrete mortars properties". Construction and Building Materials, vol. 21 (2007), no 6, pp. 1191- 1197. DOI: 10.1016/j.conbuildmat.2006.06.002.

(17) Puertas, F.; Barba, A.; Gazulla, M. F.; Gómez, M. P.; Palacios, M.; Martínez, S.: "Ceramic wastes as raw materials in Portland cement clinker fabrication: characterization and alkaline activation". Materiales de Construcción, vol. 56 (2006), n 281, pp. 73-84.

(18) Puertas, F.: García-Díaz, I.; Barba, A.; Gazulla, M. F.; Palacios, M.; Gomez, M. P.; Martínez-Ramírez, S.: "Ceramic wastes as alternative raw materials for Portland cement clinker production". Cement and Concrete Composites, vol. 30 (2008), no 9, pp. $798-805$. DOI: 10.1016/j.cemconcomp.2008.06.003.

(19) Puertas, F.; García-Díaz, I.; Palacios, M.; Martínez-Ramírez, S.; Barba, A.; Gazulla, M. F.; Goméz, M. P.: "Empleo de residuos cerámicos como materia prima alternativa para la fabricación de clínker de cemento Portland". Cemento-Hormigón, noviembre 2007, no 907, pp. 20-34.

(20) Portella, K. F.; Joukoski, A; Franck, R; Derksen, R.: "Secondary recycling of electrical insulator porcelain waste in Portland concrete structures: determination of the performance under accelerated aging". Cerâmica, no 52, 2006, pp. 155-167. DOI: 10.1590/S036669132006000300008.

(21) Gomes, M.; de Brito, J.: "Structural Concrete with Incorporation of Coarse Recycled Concrete and Ceramic Aggregates". Portugal Sb07 - Sustainable Construction, Materials and Practices: Challenge of the Industry for the New Millennium, Pts 1 and 2 (2007), pp. 887894.

(22) Gomes, M.; de Brito, J.: "Structural concrete with incorporation of coarse recycled concrete and ceramic aggregates: durability performance". Materials and Structures, vol. 42 (2009), no 5, pp. 663-675. DOI: 10.1617/s11527-008-9411-9.

(23) Cachim, P. B.: "Mechanical properties of brick aggregate concrete". Construction and Building Materials, vol. 23 (2009), no 3 pp. 1292-1297. DOI: 10.1016/j.conbuildmat.2008.07.023.

(24) Silva, J.; de Brito, J.; Veiga, R.: "Recycled red - clay ceramic construction and demolition waste for mortars production". Journal of Materials in Civil Engineering, vol. 22, no. 3, (2010), pp. 236-244. DOI: 10.1061/(ASCE)0899-1561(2010)22:3(236).

(25) Guerra, I.; Vivar, I.; Llamas, B.; Juan, A.; Morán, J. M.: "Eco-efficient concretes: The effects of using recycled ceramic material from sanitary installations on the mechanical properties of concrete". Waste Management, vol. 29 (2009), n 2, pp. 643-646. DOI: 10.1016/j.wasman.2008.06.018.

(26) López, V.; Llamas, B.; Juan, A.; Morán. J. Ma.; Guerra, M. I.: "Eco-efficient concretes: Impact of the use of white ceramic powder on the mechanical properties of concrete". Biosystems Engineering, vol. 96 (2007), no 4, pp. 559-564. DOI:10.1016/j.biosystemseng.2007.01.004

(27) Juan, A.; López, V. M.; Morán, J. Ma.; Guerra, M. I.: "Reutilización de restos de cerámica blanca como áridos para la elaboración de hormigones". Ingeniería Civil, no 146 (2007), pp. 1-5.

(28) Juan, A.; Medina, C.; Guerra, M. I.; Llamas, B.; Morán, J. Ma.; Tascón, A.: "Re-use of construction and demolition residues and industrial wastes for the elaboration or recycled eco-efficient concretes". Spanish Journal of Agricultural Research, vol. 8 (2010), no 1, pp. 25-34.

(29) Arredondo, F.: Dosificación de hormigones. Series manuales y Normas del Instituto de las Ciencias de la Construcción Eduardo Torroja, $3^{a}$ edición. Madrid (1968), pp. 187. 